\title{
Astronomers of the inward: on the histories and case histories of Alexander Luria and Oliver Sacks
}

\author{
Hannah Proctor ${ }^{1}$ (D) \\ Accepted: 26 April 2021 / Published online: 1 June 2021 \\ (C) The Author(s) 2021
}

\begin{abstract}
This essay discusses the brief but extensive correspondence Soviet neuro-psychologist Alexander Luria exchanged with his younger American colleague Oliver Sacks between 1973 and 1977, the year Luria died. Sacks, whose case histories went on to become mainstream bestsellers, always expressed his indebtedness to Luria, whose warm and detailed approach to writing about his patients' peculiar and sometimes distressing neurological conditions inspired Sacks. This essay explores this influence but also probes distinctions between the two scientists' understandings of human consciousness tied to the very different social and political contexts in which they conducted their clinical research.
\end{abstract}

Keywords Psychology · Psychiatry · Soviet Union · Alexander Luria · Oliver Sacks

\section{Inner and outer space}

Alexander Luria's case history The Man with a Shattered World focuses on the injury and partial recovery of Zasetsky, a Red Army soldier who survived a bullet wound to the head but endured severe and lasting brain injuries as a result. The book concludes with a hopeful proclamation in the voice of its protagonist:

In this age we have an opportunity to build and create a fine and beautiful world, to feed, clothe, and shelter all of mankind, not only the present generation but those for centuries to come. The water and earth of this world have an endless supply of energy and raw material, there is no need to fear any shortage of them. Soon there will be flights to outer space-first to the moon and the nearest planets. This will give us an even greater chance to enrich life with rare elements and substances that may be more plentiful on planets other than the earth. (Luria 2002, p. 160)

Hannah Proctor

hannah.proctor@strath.ac.uk

1 Unversity of Strathclyde, Glasgow, UK 
The Russian text contains a note absent from the English translation explaining that Zasetsky had written this in 1957, two years before the first Soviet space mission (Luria 1996, p. 233). Yet the hopeful communist sentiment of the book's closing pages is undercut by a more sombre reflection that appears early in the case history where Zasetsky is quoted as observing that 'there is a good deal of talk now about the cosmos and outer space', but that this interest in intergalactic exploration detracted attention from a less grandiose kind of flight that had occurred on a huge scale in recent history and which had profoundly impacted the course of his life:

the flight of a bullet, or a shell or a bomb fragment, that rips open a man's skull, splitting and burning the tissues of the brain, crippling his memory, sight, hearing, awareness-these days people don't find anything extraordinary in that (Luria 2002, p. xxi).

The possibility of a future of venturing into the cosmos and of founding an egalitarian plenitudinous society on Earth is undercut by the brutal realities of war, which, though in the past, continued to shape Zasetsky's life in the present. Zasetsky's dreams of exploration in the vast galaxies of outer space were in tension with his struggles with his own inner space; a fraught psychic space of conflict, fragmentation, finitude and disorientation. In this essay, the cosmological figures as an internal, psychic realm and is therefore also ontological.

In a letter to Luria in 1975, shortly after the publication of The Man with a Shattered World in English translation, the British neurologist Oliver Sacks, whose published works often expressed admiration of Luria's pioneering case histories (e.g. Sacks 2015a b, p. 39), recalled that as a child he had been fascinated by astronomy, a fascination which, he reflected, had persisted in adulthood but had 'transformed and turned inward':

There has been a change of direction, towards subjectivity and inwardness, but with a continuance (I hope!) of the original astronomical precision and passion; over the years, and almost against my will, I have become a sort of astronomer of the inward, focussing with extreme introspection of my own state-of-mind... but doing this (I like to think!) in order to learn something of other minds, of Mind, and not as a mere egoistic indulgence... As an astronomer peering at a new planet gradually 'sees' or 'makes out' more and more features, which become clearer and clearer and clearer as he 'concentrates' upon them; so I have felt like an 'internal astronomer', peering and gazing at landscapes of symptoms. ${ }^{1}$

Luria also dedicated his life to understanding people's internal landscapes, and Sacks expressed his great delight at receiving cheerful Soviet New Year's cards from Luria, which typically included depictions of cartoon animals or children in hammer and sickle emblazoned helmets piloting spaceships.

\footnotetext{
1 Sacks to Luria 7 June 1975, Oliver Sacks Archives. Throughout this essay I have not preserved the emphases in the letters between Sacks and Luria.
} 
This essay will discuss the brief but extensive correspondence Luria and Sacks exchanged between 1973 and 1977, the year Luria died. They never met. When they began to correspond, Sacks had just published his second book at the age of 40, and Luria, 30 years Sack's senior, had been pursuing clinical work for over four decades. Sacks, whose works would go on to be bestsellers on the scale of popular literature, was inspired by Luria's approach to writing case histories. After considering Luria's influence on Sacks and some of Sacks's reservations about Luria's work, the essay will discuss aspects of Luria's approach that Sacks overlooked or downplayed which relate to the specificities of the Soviet context in which Luria's work developed, but will caution against drawing too neat a distinction between the two scientists along political lines.

\section{Double personalities}

In a review article published in The Listener in 1973 which prompted Luria to make contact with his younger colleague for the first time, Sacks characterised the Soviet scientist as a 'divided man' whose work was split between texts 'marked by a certain impersonality and coldness of style which match the "objectivity" of approach they embody' and those which conveyed 'the infinite complexity of human nature and human beings... the texture of human thought, perception and action, the ways this can be damaged or disordered, and the ways it can be reconstituted' (Sacks 1973, p. 871). In his response, Luria rebutted this characterisation of his work insisting that 'only the style of these two books [his two 'romantic' case histories The Mind of a Mnemonist and The Man with a Shattered World] is different from others, but the principle remains the same'. Luria expressed his frustration that Sacks incorrectly described him as a student of Ivan Pavlov (1849-1936) and, hence, as a proponent of Pavlovian ideas concerning conditioned reflexes_-far from being a student of Pavlov, Luria pointed out that he had been denounced for being insufficiently Pavlovian (and he was forced to 'repent' at the infamous Pavlovian Session of 1950). He protested that he had only even met Pavlov twice and certainly didn't study under him.

Pavlov died in 1936, but his work on conditioned reflexes was pronounced compatible with dialectical materialism and provided the dominant paradigms within Soviet psychiatry throughout the Stalin era and beyond (although, as Benjamin Zajicek discusses, there was not always a clear consensus on how these theories were interpreted; Zajicek 2009). More mechanistic and less concerned with the social than Luria, Pavlov advanced a physiological understanding of higher mental functions. Luria chartered a different course. Luria was born in Kazan in 1902, where he attended university in the immediate aftermath of the October Revolution. He moved to Moscow in 1923 at the invitation of K.N. Kornilov, who had recently become director of the Institute of Psychology. He also took on the role of Scientific Secretary of the Russian Psychoanalytic Society and was active in the small psychoanalytic community in the city until Freud was effectively banned in the Soviet Union in 1930 (Etkind 1997; Miller 1998). In 1924, Luria met Lev Vygotsky, which he would refer to throughout his life as a decisive 
turning point in his intellectual formation (Luria 1979, p. 73). Luria encouraged Kornilov to find a role for Vygotsky at the Institute of Psychology, and they collaborated until the latter's death in 1934. Luria claimed that his subsequent research built on their earlier work together by continuing to elaborate an understanding of human cognition and development that situated individual subjectivities in the context of their specific social, cultural and historical circumstances. This early period in Luria's career coincided with a period of relative eclecticism and experimentation in the Soviet psy-disciplines during which psychiatrists and psychologists debated what a properly materialist and Marxist approach could look like, while remaining in dialogue with psychiatric developments in Western Europe and North America (see Joravsky 1989; Kozulin 1984; Wortis 1950).

After a brief period working in Kharkiv, Luria returned to Moscow but lost his position at the Medico-Genetic Institute in 1936 following a decree from the Party's Central Committee banning pedology and outlawing disciplines that took a 'bio-sociological' approach (Wortis 1950, pp. 242-245). Vygotsky's work remained largely out of print until the late 1950s (van der Veer and Yasnitsky 2016). At the height of the purges, Luria sheltered by working as a physician, receiving a medical qualification in 1937, after which his research extended to encompass neurological investigations (Akhutina 2012, p. 6). Though a heterogeneity of approaches could not be pursued openly throughout the Stalin era, Luria picked up many threads of his early research interests once again in the mid 1950s. Despite shifting between numerous disciplines and institutions, often due to changes in the political climate, Luria's central concerns remained remarkably consistent across his long career. He coined the term 'neuropsychology' to describe the 'synthetic' scientific discipline he propounded, a neurological approach that refused to treat brains as isolated organs but situated them in people and people in relation to the surrounding world (Luria 1973, p. 105).

Luria not only rebutted Sacks's remarks about Pavlov but also contested Sacks's dismissal of the work of the influential Russian neurologist Ivan Sechenov (1829-1905) as being 'permeated by mechanical and cadaveric images' (Sacks 1973, p. 870) and unconcerned with living people, bristling at Sacks's implication that some of Luria's work betrayed similar qualities. In contrast to this deathly image, in outlines of his ideal approach to science, Luria cited Johann Wolfgang von Goethe: 'grey is every theory but ever green is the tree of life' (Luria 1979, p. 57). Luria's work on the grey matter of the brain refused to analyse neuronal functioning in isolation from people and, by extension, refused to analyse people in isolation from the social and cultural world they inhabited. Luria characterised his case histories as belonging to a lost tradition of 'romantic science' with its roots in the nineteenth century, contrasting these to the grey 'classical' approach typical of most twentieth-century scientific writing. Sacks may not have initially believed that all of Luria's works conformed to this 'romantic' model, but he did perceive the vitality of Luria's case histories, which he described as 'histories of life' (Sacks 1991, p. 280). Luria also outlined two contrasting approaches to science in his first letter to Sacks, declaring his allegiance to the 'romantic': 'it is a kind of 'Romantic Science' which I wanted to introduce, partly because I am strongly against formal statistical approach and for 
a qualitative study of personality, for every attempt to find factors underlying the structure of personality'. ${ }^{2}$

For Luria, the romantic scientist should seek to convey the qualitative specificity and idiosyncrasy of human consciousnesses:

Romantics in science want neither to split living reality into its elementary components nor to represent the wealth of life's concrete events in abstract models that lose the properties of the phenomena themselves. It is of the utmost importance to romantics to preserve the wealth of living reality, and they aspire to a science that retains this richness. (Luria 1979, p. 174)

Luria was not concerned with describing symptoms in isolation from a person's whole personality, but hoped that his granular writing style and empathetic therapeutic approach would allow for the preservation of 'the manifold richness of the subject' (Luria 1979, p. 178). In The Mind of a Mnemonist (1968), which explores the perceptions and life trajectory of a synesthete patient called Shereshevsky (referred to simply as S. in the book) with whom Luria worked over the course of many years, Luria asserted:

In this book I attempted to analyze the structure of the personality of a man who possessed an exceptional (in practice, unlimited) synesthetic memory. I concentrated not so much on the special features of his memory as on the consequences that this extraordinary memory had for the structure of the entire personality. (Luria 1974, p. 285)

Though The Mind of a Mnemonist described Luria's patient's extraordinary capacity to remember and that capacity's connection with intense mergings of sensuous experience, it also emphasised the often alienating effects this had on Shereshevsky in his everyday life: at work, in his personal relationships and in his relation to his future. Rather than reifying particular mental states, romantic science sought to present not diagnostic categories but the people living with them, understood as social beings irreducible to specific pathologies.

Sacks, who first saw Luria deliver a lecture in London in 1958 and almost a decade later began reading works by Luria available in English (Sacks 2015a, b (2), p. 178), was influenced by Luria's attempt to reunite science with art, declaring enthusiastically: 'the vision of such a poetic science, a total fusion of Art and Science, grips my heart and my mind with equal force, and tantalizes with glimpses of an old unity restored'. ${ }^{3}$ In expressing his desire to write with empathy and warmth about his patients, he credited Luria as an inspiration: 'if there is anyone who has taught me this, more than anyone living, it is you, with your wonderful, profound but so unassuming 'biographic' histories'. ${ }^{4}$ Sacks followed Luria in attempting to convey the peculiarities of subjective experiences to a readership who perceived the world in more conventional ways. But in both their works this compulsion to faithfully

\footnotetext{
${ }^{2}$ Luria to Sacks, 19 July 1973, Oliver Sacks Archives.

3 Sacks to Luria, 14 June 1975, Oliver Sacks Archives.

${ }^{4}$ Sacks to Luria, 24 December 1975, Oliver Sacks Archives.
} 
describe was combined with their clinical roles in helping their patients to overcome, adjust to or compensate for their conditions in various ways.

\section{Through the looking glass: exercises in empathy}

The Mind of a Mnemonist opens with an epigraph from Lewis Carroll's Alice Through the Looking Glass. Luria declares his intention to take his readers 'past the smooth, cold surface of the looking-glass' to explore the unfamiliar world on the other side; 'a wonderland, where everything is at once so familiar and recognizable, yet so strange and uncommon' (Luria 1975, p. 5). Sacks noted in his correspondence with Luria that 'you couldn't write as you do unless you knew your patients from "inside"; an intense exercise of the Mnemonist or The Shattered Man'. In his early book Awakenings, focused on post-encephalitic patients, which Luria read and admired, Sacks described his own intention to write about his patients' experiences as having a similar aim: to convey 'other worlds, other lives, [which] even though so different from our own, have the power of arousing the sympathetic imagination' (Sacks 1991, p. xxxviii).

The Man with a Shattered World attempts to convey Zasetsky's perceptions to the reader from 'inside', both through descriptions of his experiences and through its formal structure. Luria relates how objects for Zasetsky 'would glimmer fitfully and become displaced, making everything appear as if it were in a state of flux' (Luria 2002, p. 38) or confronted him as 'alien, colourless and fragmented' (Luria 2002, p. 99). Citations from Zasetsky's own writings give a sense of his bewilderment and disorientation: 'I see only a grey mist in which spots, threads, and little bodies seem to shift and flicker back and forth' (Luria 2002, p. 75). The non-linearity of the case history's structure and its often fragmentary, ellipsis-strewn passages participate in presenting the subject of the case history as a person rather than a set of symptoms as viewed from the outside. Similarly, in The Mind of a Mnemonist, Luria gives a granular description of the intense sensations that characterised his patient's condition. Despite having no knowledge of Hebrew, in childhood Shereshevsky had been able to recite long passages of the Torah aloud because the sounds registered as a series of splashes or puffs of steam that he could reproduce exactly in his mind. He created elaborate worlds in his head to reconstruct things, and all of his psychic fabrications were as imperishable as his memories of the external world. He would be able to reproduce a meaningless equation many years later by recalling the narrative he had constructed around it when he first saw it. Often, he would memorise passages of text or long series of numbers by reconstructing a journey around Moscow, inserting landmarks along the route that corresponded to specific words. He would then be able to repeat this 'journey' and reproduce all that he saw along the way, only stumbling if he had accidentally placed an object in an inconspicuous place: 'Sometimes I put a word in a dark place and have trouble seeing it as I go by' (Luria 1975, p. 33). Sacks described the book as exploring 'the foliage of his memory-tree,

\footnotetext{
5 Sacks to Luria June 14 1975, Oliver Sacks Archives.
} 
the toys in his memory-shop, the inhabitants of his memory-house, the icons and windows in his memory-church, the squares and streets and buildings and people which lead a life of their own, almost unnaturally, theatrically real, in the teeming city of his memory-mind' (Sacks 1973, p. 871).

Luria's patient found it difficult to follow stories, as the narrative would be obscured by the rush of images associated with individual words or syllables. He was often unable to follow the meaning of a conversation as he would be distracted by the taste or smell produced by a person's voice. He noted that Vygotsky had a voice like crumbly cheese, whereas the film director Sergei Eisenstein seemed to speak with many voices at once, which was more like a bouquet: 'listening to him it was as though a flame with fibers protruding from it was advancing right toward me (Luria 1975, p. 26). ${ }^{6}$ In conversation he would 'digress endlessly', distracted by his elaborate chains of association (Luria 1975, p. 116). The words he encountered provoked such vivid visual associations that meaning was scattered, disrupting his ability to follow instructions or conversations: 'at each step he had to contend with superfluous images and sensations' (Luria 1975, p. 104). He found it difficult to remember faces because he experienced them as 'changing patterns of light and shade' (Luria 1975, p. 53).

Shereshevsky's rich interior life overshadowed his connection to his immediate surroundings: '[at] times smoke or fog appears.... and the more people talk, the harder it gets, until I reach the point where I can't make anything out' (Luria 1975, p. 35). Luria characterised Shereshevsky's life as 'a struggle against images that kept rising to the surface of his mind' (Luria 1975, p. 87). He dealt with the world, including his relationships with his closest family members, 'as though through a haze' (Luria 1975, p. 118). Unlike in Sacks's The Man Who Mistook His Wife for a Hat (1985), which includes examples of people who seem joyfully lost in reveries or reminiscences of childhood as a result of brain tumours, Luria insists that Shereshevsky's case was tragic. Luria's role as a clinician was not merely to describe his patient's 'haze' (or Zasetsky's 'grey mist'), however, but to help dispel it. Luria documented Zasetsky's 'problems of coping with a world that seemed to have disintegrated', but the case history also documents Luria's own attempts to assist his patient reintegrate into and participate in society (Luria 2002, p. 51).

\section{From fragmentation to wholeness: therapeutic rehabilitation}

Luria was an avid reader of detective novels. In 1975, Luria requested Sacks send him paperbacks by Nicolas Freeling 'who to me is one of the real best detective, or psychological detective, writers', requesting Double Barrel, Criminal Conversation, The Ring of the Rainy Country, The Dresden Green and Strike Out Where Not Applicable. ${ }^{7}$ Sacks in turn described Luria as a 'great Detective who is, equally and

\footnotetext{
${ }^{6}$ For a detailed discussion of the relationship between S., Eisenstein and Luria, see Proctor (2020).

${ }^{7}$ Luria to Sacks, 4 August 1975, Oliver Sacks Archives.
} 
necessarily, a great Reconstructor'. ${ }^{8}$ Sacks recalled that Luria's favourite Sherlock Holmes book was the Seven Percent Solution, in which a cocaine-addicted Holmes is in analysis with Freud (Cole, Bruner, Sacks 2013). Luria, who in the 1920s had himself conducted experiments with people accused of murder in collaboration with the police in Moscow, explicitly likened the role of the psychologist to that of a 'criminal investigator' (Levitin 1998, p. 27). He wrote to Sacks in 1975:

The method of recovering the whole structure of events, putting the pieces together (in no way making the opposite - splitting the whole to pieces and reducing the most complicated whole to its parts). That is what we have in both- in medicine and in detective stories. ${ }^{9}$

Sacks conceived of case histories as narratives that seek to reorient the subject in a world experienced as broken and strange. 'Clinical tales' not only describe relationships between 'organisation and chaos, order and disorder' but attempt to mimic healing processes that aim to restore or instil the former and overcome the latter (Sacks 1986, p. 18). Zasetsky, the patient-protagonist of Luria's case history The Man with a Shattered World, framed his struggle in similar terms, as an attempt to make 'the bits and pieces to add up to a coherent whole' (Luria 2002, p. xxi). Luria noted of his patient that initially his 'only material consisted of fragmentary recollections that came to mind at random. On these he had to impose some order and sense of continuity' (Luria 2002, p. xx). This sense of reorientation is also captured by the Russian title of Luria's case history: Poteriannyi $i$ vozvrashchennyi mir [A World Lost and Re-Gained]. Luria suggested that Sacks should give a similar title to the case history that was eventually published as A Leg to Stand On (1984). ${ }^{10}$

Sacks noted admiringly of Luria's therapeutic approach in a letter that it seemed to him that Luria did "not do things to patients, but explore[d] with them (and for them)... The patient is your co-explorer, your coworker, in this therapeutic enterprise; he enjoys with you a sense of co-action, you do not impose passivity on him but assist him to find useful modes of activity'. ${ }^{11}$ Writing played a therapeutic role in Luria's treatment methods, yet Zasetsky's case also attested to the limits of the practice by documenting the frustrations Zasetsky felt in trying to produce, let alone conclude, a written narrative:

I tried to remember whatever I could with that battered memory of mine and write it as a true story, just as a writer would. But when I started I realised I'd never be able to do that since I didn't have enough of a vocabulary or mind left to write well. (Luria 2002, p. 79)

Sacks had been far more critical of Luria's methods in his Listener article, where he claimed that Zasetsky's strenuous efforts to recover seemed like a waste given that full recovery remained an impossibility. Here the implication was that, instead

\footnotetext{
${ }^{8}$ Sacks to Luria, 24 December 1975, Oliver Sacks Archives.

${ }^{9}$ Luria to Sacks, 1 July 1975, Oliver Sacks Archives.

10 Sacks to Luria, 21 March 1976, Oliver Sacks Archives.

11 Sacks to Luria 22 February1974, Oliver Sacks Archives.
} 
of co-exploring, Luria attempted to impose order on Zasetsky's shattered world rather than acknowledging that the fragments could not be pieced together to make a whole; Zasetsky's lost world could not be fully re-gained. ${ }^{12}$ Luria's 'obstinate and at times almost cruel' insistence that he continue in the face of the impossibility of his patient's full recovery, seemed to Sacks to exhibit a commitment to the systemic and to a normative conception of healthiness that came at the expense of the particular needs and capacities of the patient (Sacks 1973, p. 872).

Sacks responded to Luria's initial castigating letter regarding his article at length, apologising profusely for its mistakes, and he sent a corrective note to be published in a subsequent issue of The Listener. Sacks and Luria then corresponded regularly until the latter's death in 1977. The long, digressive, confessional, philosophical and self-avowedly neurotic letters Sacks sent to Luria from London, Switzerland and New York tended to be met with concise and professional replies from Moscow. Although Luria was never cold, curt or dismissive in his interactions with Sacks and sometimes evinced a keen interest in the latter's research and publications, nothing he wrote in their exchange came close to matching the emotional intensity or intellectual detail — not to mention the sheer length — of his correspondent's verbose epistles. Luria may have resisted being described as being a 'divided man', but the stark contrast Sacks observed between Luria's publications found a counterpart in these letters between the two scientists, with the romanticism of Sacks being offset by Luria's more 'classical' tone. Indeed, Sacks's descriptions of his own approach to writing as 'endless, often compulsive, sometimes confessional' ${ }^{13}$ sound like Luria's descriptions of Zasetsky's arduous scribblings: 'I am tempted more and more to idiosyncratic, improvised, aphoristic forms and away from Treatises with a clearly defined beginning, middle and end'. ${ }^{14}$ Sacks insisted that he saw his tendency to proliferate drafts and add 'footnotes' or 'footnotes to footnotes' to existing works as a strength of the final publications: whose 'originality (I think) lies in... 'fragmentariness' rather than in any systematic final conclusive qualities'. ${ }^{15}$ Luria's case histories retain a fragmentary quality in keeping with the conditions they describe, but they were nonetheless distilled from pages and pages of notes, and Luria always emphasised their concision, whereas Sacks embraced the open-ended, digressive and inconclusive. ${ }^{16}$

In A Leg to Stand On, published after Luria's death but which incorporated insights into the experience of recovering from a leg injury that Sacks first relayed to Luria in a series of long letters, a hint of his initial criticisms of Luria's more 'classical' works resurfaced. His original critique in The Listener argued that in The

\footnotetext{
12 This recalls Catherine Malabou's criticisms of both Luria and Sacks (Malabou 2012, p. 53). My interest in Luria grew out of an engagement with Malabou's discussions of his work (Proctor 2011; Proctor and Salisbury 2015).

13 Sacks to Luria, 3 August 1973, Oliver Sacks Archives.

1413 April 1974 Sacks to Luria.

1513 April 1974 Sacks to Luria.

16 Zasetsky produced over three thousand pages of notes as Luria recalled: 'Before me is a pile of notebooks: some of them faded, makeshift affairs dating from the war years; others, thick, oilcloth-covered books covering the recent past' (Luria 2002, p. xix).
} 
Man with a Shattered World Luria 'gives us a wealth of observations which in their exactness, their coherence, their beauty, their unity, bear the inimitable stamp of verisimilitude, of truth: but he proceeds from these superb observations to conclusions which are not only without sense in themselves but in total contradiction to everything he has observed and displayed so well' (Sacks 1973, p. 873). In his later book, Sacks similarly noted a curious disparity between the peculiarity of the condition neuropsychological works describe and the pat or systemic conclusions that often accompany them. In this discussion, rather than citing Luria himself, he mentions instead Rehabilitation of Hand Function, a work by Luria's sometime collaborators Aleksei Leontiev and Alexander Zaporozhets, which was based, like Luria's case history of Zasetsky, on work conducted with people injured during the Second World War.

In 1942, Luria had set up a 400-bed sanatorium known as Evacuation Hospital No. 3120 in Kisegach near Cheliabinsk in the southern Urals, overseeing the construction of laboratories and therapeutic training rooms. There he worked with a team of 30 researchers, including people with whom he had collaborated in his earlier career in Moscow and Kharkiv, whose tasks were to diagnose and treat brain injuries. ${ }^{17}$ They worked to develop 'rational, scientifically based techniques for the rehabilitation of destroyed functions' (Luria 1979, p. 139). Documenting work aimed at rehabilitation, Luria's Traumatic Aphasia, published in the USSR in 1947, drew on this wartime work (Luria 1970). Rehabilitation of Hand Function discusses therapeutic techniques developed with patients with amputated hands, which, like methods discussed by Luria, involved practical tasks and encouraged patients to relearn forgotten skills, which Luria described as 'adaptation to new circumstances not to regeneration and restoration' (Luria 1963, p. 33). The book shares with Luria's wartime work an emphasis on compensation for lost capacities and emphasises the plasticity of the brain and hence of the whole person. ${ }^{18}$

Alongside discussions of phantom hands, the authors describe a patient who had previously worked as a carpenter on a collective farm but who lost his eyes and forearms after being wounded in April 1943 and who 'very acutely and painfully experienced 'disappearance' of the world of objects' (Leontiev and Zaporozhets 1960, p. 56). According to Sacks, however, despite gesturing towards the strange and bewildering experiences of the patients it discusses, the book's conclusions are 'mechanical, analytic, cybernetic and are couched entirely in terms of "systems" and the individual perspective is smothered by general formulations: "the "you", or the "I" which is everywhere implicit is formally, explicitly denied or disallowed' (Sacks 1984, pp. 163-164). ${ }^{19}$ Sacks characterises this tension as a 'peculiar double-think'

\footnotetext{
17 Benjamin Zajicek discusses experiments conducted by Lev Perel'man and Bliuma Zeigarnik investigating 'deaf-mute syndrome' at the Kisegach hospital (Zajicek 2009, pp. 144-149).

18 For the purposes of this article, I am following Sacks in treating Rehabilitation of Hand Function as broadly similar in its therapeutic approach, style and understanding of brain function to Luria's own wartime publications. To understand theoretical divergences between Leontiev, Luria and others within the 'Vygotsky circle', see van der Veer and Yasnitsky (2016) and Leontiev (2005).

19 He makes a similar point in the book's concluding pages and again claims that, though Luria appreciated the necessity for describing syndromes, he still clung to systems (Sacks 1984, pp. 188-189).
} 
evident not only in this book, but in neuropsychology in general (akin to the division he previously attributed to Luria) (Sacks 1984, pp. 163-164). Though he imbues it with a different meaning, Sacks's use of the term 'doublethink' here, borrowed from George Orwell's 1984, has a casually anti-Soviet ring to it, as if he was vaguely hinting that the Soviet scientists' reductive portrayals of their patients were akin to Soviet state oppression. ${ }^{20}$

According to Sacks, neuropsychology treats living human subjects as though they were objects: 'it is precisely the subject, the living "I", which is being excluded' (Sacks 1984, p. 164). He argues that Luria 'himself felt this - intensely', which explained why in 'his last years, without any sacrifice of objectivity or accuracy, he introduced the subject more and more - at the centre' of his work (Sacks 1984, p. 164). Even if Sacks is correct to note that very little detail is provided in Rehabilitation of the Hand about patients' emotional states or everyday lives (something that could equally be said of the short and perfunctory cases in Luria's Traumatic Aphasia), Sacks's assumption that Luria's romantic science was primarily concerned with 'suffering, acting' individuals overlooks the significance of the collective both to Luria's case histories and to Leontiev and Zaporozhets's co-written book (Sacks 1984, p. 164). It should also be stressed that, though most of Luria's books bore only his name, almost all of his research, including in the Urals, was conducted collaboratively, whereas Sacks in his letters to Luria constantly stressed his isolation from other colleagues. $^{21}$

Leontiev and Zaporozhets note that when their wounded patients first began to arrive at the field hospital, the occupational therapy workshops intended for their treatment were not yet completed, which the psychiatrists worried would have adverse effects on their patients. Yet these concerns proved to be without foundation because they instead found that the patients "were attracted by the creative task of organizing a new type of treatment centre... the deficiencies which existed were in fact a source of great encouragement in their work to the wounded patients' (Leontiev and Zaporozhets 1960, p. 149). Indeed, they observe that when the workshops were completed there was a lull in energy and activity from the patients, some of whom lost morale and motivation. It was then decided that the workshops would manufacture window frames and furniture to replace items destroyed in the Battle of Stalingrad, which succeeded in rousing the interest of the patients, leading them to conclude that 'the social significance of the product is a source of encouragement to the patient in his activity and must always be borne in mind in the organization of an occupational therapy programme' (Leontiev and Zaporozhets 1960, p. 150). Luria similarly situated his research during the Second World War in the context of

\footnotetext{
${ }^{20}$ Sacks frequently railed against mechanistic understandings of human consciousness. His insistence that 'we are in no sense machines or impersonal automata' was not expressed in political terms but does echo commonplace Western characterisations of the Soviet Union in the Cold War era (Sacks 1984, p. 188). In an obituary of Luria, Sacks contrasted Luria's 'ultimate concern with the human condition' with mainstream Soviet Pavlovian approaches, but Luria's differences from Pavlov did not make his work any less Soviet (Sacks 1977).

21 Sacks to Luria, 2 August 1973, Oliver Sacks Archives. For an analysis on the centrality of collaboration for the psychologists who worked with Vygotsky, see Stetsenko and Arievitch 2004.
} 
a collective endeavour: 'Each of us knew we had an obligation to work together with our countrymen to meet the challenge. We each had to find our place in the struggle' (Luria 1979, p. 138), a sentiment that was echoed by Zasetsky, who bewailed no longer being 'of some service to his country' (Luria 2002, p. 35).

Luria took inspiration from neurologists who themselves developed theories of aphasia specifically and of brain function more generally after working with people injured in war, including Kurt Goldstein and Henry Head, with whom Sacks' father had trained in Britain (Goldstein 1942; Head 1926). ${ }^{22}$ These scientists both worked with soldiers injured in the First World War, and they too emphasised the social function of their work. Like Goldstein, Luria emphasised the capacity for adaptation and readjustment, as well as being committed to clinical empathy. Luria followed Head in observing patients over long periods of time and similarly cast his patients as 'willing collaborators' in the therapeutic process (Jacyna 2000, pp. 150-170). All three neurologists shared an understanding of brain wounds as both physical and psychological.

Anne Harrington discusses Goldstein's research in relation to German understandings of holism, explaining how Goldstein's brain-injured patients provided insights into humanity that chimed with his vision of society, arguing that his work was imbued with a culturally specific political meaning rooted in Weimar Germany, 'a reflection of his own liberal hopes for Germany' (Harrington 1996, p. 154). Could Luria's work be interpreted instead as a reflection of communist hopes for the Soviet Union? Though the patriotic and collectivist rhetoric adopted by Luria in texts based on his wartime work, most explicitly in The Man with a Shattered World, was often consistent with Soviet discourse, many of his assumptions about brain function built on the work of neurologists working in Western Europe. Sacks at times caricatured Soviet society and psychiatry as monolithic while at others seemed to forget that Luria was Soviet at all. Luria's work may resist neat characterisation along political lines precisely because it was simultaneously particular to its Soviet context without being reducible to it, influenced by Marxism but also by Western science and romantic traditions.

\section{Case histories as/in history}

In the first letter he sent to Sacks, after explaining that he had never been a student of Pavlov, Luria declared:

I am only a pupil of Lev Vygotsky - the real genius of Soviet science... His starting point was that complex psychological processes have not an inner (biological) origin, don't start in the depths of the brain, but are the result of a social origin. $^{23}$

\footnotetext{
22 Sacks to Luria, 3 August 1973, Oliver Sacks Archives. For a discussion of the influence of Goldstein and his collaborator Adhamar Gelb on Luria's work, and Luria's influence on contemporary neuroscience in turn, see Christensen and Prigatano (2009).

23 Luria to Sacks, 19 July 1973, Oliver Sacks Archives (transliteration modified for consistency).
} 
Yet the specificities of the different societies in which Luria and Sacks conducted their clinical work - and in which they and their patients lived - did not feature explicitly in their correspondence. Indeed, Sacks declared that their geographical separation and the ideological and political divisions between their two countries did not reflect a division between them:

We are so strangely different, so strangely similar! Your letter once came to me like a revelation from 'the other side', piercing the 'Iron Curtain', showing that in reality, in humanity, there is no 'other side', only foolish barriers which cut us off from each other. ${ }^{24}$

Despite all they shared, distinctions between their approaches can be discerned by considering the cases they chose to focus on: what can be gleaned about history from reading case histories?

Zasetsky's injury had a clear social aetiology, and he understood his cognitive condition in relation to the conflict that produced it: 'he could not understand why the world had become so peculiar, why war was necessary, or find any justification for what happened to him' (Luria 2002, p. 158). Some passages also suggest that he blamed war for putting an end to the possibility for building a communist society: 'were it not for war, the world would have become a great place to live long ago' (Luria 2002, p. 160). He asks poignantly: 'What need is there for war, violence, slavery, oppression, murder, executions, poverty, hunger, back-breaking work, or unemployment in countries that have so much wealth?' (Luria 2002, p. 159). (The English translation is a little coy here; the Russian original says simply: 'in capitalist countries' (Luria 1996, p. 233).) The cerebral location of Luria's patient's lefthemisphere injury accounted for his acute sense of loss, his painful awareness of what had befallen him and thus for his determination to recover (Luria 2002, p. 34). Despite the enormous problems he faced, this enabled him to retain the capacity to make and carry out plans. In contrast, Sacks's The Man Who Mistook His Wife for a Hat (1985) focuses on people with right-hemisphere disorders who not only lost their grasp of reality but remained unaware of this loss (Sacks 1985). Sacks contrasted his personal experience of a broken limb to Zasetsky's experience of brain injury, noting that the 'fragments of function' Luria's patient retained enabled 'systematic reconstruction, joining together the bits which had been sundered', whereas his injury, though more specific and confined, left behind 'not a trace, not a ghost... not the faintest or most fleeting residue of function'. ${ }^{25}$ Sacks claimed that Luria's therapeutic approach was premised on a particular kind of subject: 'The Lurian method reconstitutes knowledge, but presupposes an affirmative will-to-be, to have, to become... I felt I had no cognitive starting-point for the reconstitution of knowledge, but that there was an intense disbelief and disaffimation'. ${ }^{26}$

\footnotetext{
24 Sacks to Luria, 2 August 1973, Oliver Sacks Archives.

25 In A Leg to Stand On, which Sacks dedicated to Luria and about which they corresponded at length, Sacks notes that most of the examples discussed in Luria's Higher Cortical Functions in Man are similarly concerned with the left hemisphere (Sacks 1984, p. 165; see also Luria 1966).

26 Sacks to Luria, 30 June 1975, Oliver Sacks Archives.
} 
In an essay published in the year of the fall of the Berlin Wall, Jacqueline Rose suggested that the cases that appeared in Sacks's Man Who Mistook His Wife for a Hat, so different from Freud's and from Luria's in their subjects' obliviousness to having lost their senses of self, seem like literal manifestations, 'a bodying forth', of descriptions of postmodernity that could be found in the works of theorists like Fredric Jameson, which treat the psyche as a metaphor for the postmodern (Rose 1989 , p. 241). It would be tempting to read Sacks's and Luria's respective cases as metaphors for the societies that produced them (substituting Rose's interest in the distinction between the modern and postmodern for one between communism and capitalism). Rose goes on to question, however, 'the effects of this use of a psychic metaphor (or the psychic as metaphor) for the postmodern- whether the psychic can serve at this level of generality as the model for a whole epoch [or country], whether finally the implication of the psychic and the social is best thought in this way' (Rose 1998, p. 241).

However, the case of S. is less amenable to such a metaphorical and political reading than The Man with a Shattered World. Of course he lived in a particular time and place, which shaped his life and how he interpreted his condition, but his synaesthesia was not a direct result of historical circumstances, and his psychic condition resulted in an alienated, day-dreamy disposition that stands in contrast to Zasetsky's heroic determination to recover. Sacks compared a patient with Tourette's to Luria's 'mnemonist': 'he will respond in action-to the sound, the "texture", the "feel", of each word, and then, in turn, he will respond to his responses so that he is rapidly transported through a sort of delirium of associations, all of compelling intensity, and may of his own doing, lose the point of what is actually being said'. ${ }^{27}$ Though Sacks's patient worked on Wall Street, while Luria's patient worked as a journalist before performing mnemonic feats on stage (and apparently refused the offer of working for the secret police) ${ }^{28}$ the two men seem to have shared a sense of detachment from their daily lives and a propensity for day-dreaming. Sacks wrote that his patient was 'perpetually on the brink of Action, never able to make any decisive move, and tending to lose himself in waiting - and in dreams', which reminded him of Luria's description of Shereshevsky:

He lived in wait of something that he assumed was to come his way, and gave himself up to dreaming and 'seeing' far more than to functioning in life. The sense he had that something particularly fine was about to happen remained with him throughout his life - something which would solve all his problems and make his life simple and clear. He 'saw' this and waited... Thus everything he did in life was merely 'temporary', what he had to do until the expected would finally come to pass. (Luria 1975, p. 117)

\footnotetext{
27 Sacks to Luria, 21 March 1976, Oliver Sacks Archives.

28 Johnson 2017. This article, which reveals fascinating discrepancies between Luria's account and his patient's own version of events and discusses S.'s biography in more detail than Luria's case history, reads Shereshevsky's condition as being at odds with the Soviet state rather than as metaphor for it: 'Shereshevsky had made a living off his memory in a land ruled by amnesia'.
} 
Unlike the stark contrast between The Man with a Shattered World and Sacks's case histories dealing with people with right hemisphere disorders, these two patients seemed to have much in common. People may be shaped by specific historical circumstances, but they are not merely metaphors for history. Yet a subtle difference between Luria and Sacks might be discerned not in their patients' conditions, but rather in their attempts to describe those patients. Sacks described his Tourette's patient as being 'like a man outside History, absolutely unmoored and disoriented, in a constant movement of ever-changing, bewildering, meaningless moments', ${ }^{29}$ but Luria insisted on seeing all people as existing inside history regardless of their subjective experiences of the world.

Sacks remarked that his scientific method 'starts from the most concrete, particular and individual experience, and then burrows downwards and inwards... I do not feel that I am ascending to deductions, nor do I feel that I am extending to deductions; I feel that I am descending, deeper and deeper, towards the bedrock, the foundation, of my experiences' ${ }^{30}$ Luria, on the other hand, took a more dialectical and materialist approach and invoked Marx's 'strange-sounding expression "ascending to the concrete", (Luria 1979, p. 178). ${ }^{31}$ Luria's work documented people who departed from Soviet ideals of human nature-people who perceived the world as surreal, fragmented or swirling - and as we have seen, his work had various influences, yet his insistence on situating people within a social world was distinctly Marxist. ${ }^{32}$ While Sacks wrote that he turned away from outer space to consider the inner workings of the mind, Luria always insisted that people's subjectivities could not be understood in isolation from the social and political world surrounding them. If Sacks was an astronomer of the inwards, then Luria was a psychologist facing outwards.

\section{Declarations}

Conflict of interest On behalf of all authors, the corresponding author states that there is no conflict of interest.

Open Access This article is licensed under a Creative Commons Attribution 4.0 International License, which permits use, sharing, adaptation, distribution and reproduction in any medium or format, as long as you give appropriate credit to the original author(s) and the source, provide a link to the Creative

\footnotetext{
29 Sacks to Luria, 21 March 1976, Oliver Sacks Archives.

30 Sacks to Luria, 7 June 1975, Oliver Sacks Archives.

31 Typically, Luria does not go into detail about what he understands Marx to mean by this. Capital, vol 1 is written according to this method, and the philosophical and scientific implications of the relationship between abstract and concrete in Marx are discussed in detail by Ilyenkov (Ilyenkov 2008). Luria's oblique statement seems to align with Vygotsky's professed intention to adopt 'Marx's method' in order to create his 'own Capital' (Cole et al. 1978, p. 8).

32 Following the preoccupations evident in their brief correspondence, my discussion has focused on how Luria's romantic case histories influenced Sacks, rather than comparing their respective research methods. Analysing how a distinction between 'descending... towards the bedrock' and 'ascending to the concrete' manifested in practice and exploring the political implications of those approaches would require another paper to be written.
} 
Commons licence, and indicate if changes were made. The images or other third party material in this article are included in the article's Creative Commons licence, unless indicated otherwise in a credit line to the material. If material is not included in the article's Creative Commons licence and your intended use is not permitted by statutory regulation or exceeds the permitted use, you will need to obtain permission directly from the copyright holder. To view a copy of this licence, visit http://creativecommons.org/ licenses/by/4.0/.

\section{References}

Akhutina, T. V. (2012). A. R Luriia: zhiznennyi put' [A.R. Luria: The Way of Life]. Kul'turnoIstoricheskaya Psikhologiia, 2, 2-10.

Christensen, A. and G. P. Prigatano (2009). The Bedside Neuropsychological Examination and Luria's Influence. Luria's Legacy in the 21st Century, In A. Christensen, E. Goldberg, and D. Bougakov (Eds.), Oxford: Oxford University Press.

Cole, M., Bruner, J., \& Sacks, O. (2013). A Dialogue about Alexander Luria. Dubna Psyanima Journal, $1,41-49$.

Cole, M., John-Steiner, V., Souberman, E., \& Scriber, S. (Eds.). (1978). Mind in Society: Development of Higher Psychological Processes. Cambridge, MA: Harvard University Press.

Etkind, A. (1997). Eros of the Impossible: The History of Psychoanalysis in Russia. Boulder, CO: Westview Press.

Goldstein, K. (1942). Aftereffects of Brain Injuries in War. New York, NY: Grune and Stratton.

Harrington, A. (1996). Reenchanted Science: Holism in German Culture from Wilhelm II to Hitler. Princeton, NJ: Princeton University Press.

Head, H. (1926). Aphasia and Kindred Disorders of Speech. Cambridge: Cambridge University Press.

Ilyenkov, E.V. (2008). The Dialectics of the Abstract and Concrete in Marx's Capital. Trans. S. Syrovatkin. Delhi: Aarkar.

Jacyna, L. S. (2000). Lost Words: Narratives of Language and the Brain, 1825-1926. Princeton, NJ: Princeton University Press.

Johnson, R. (2017). The Mystery of S. The Man with an Impossible Memory. The New Yorker, August 122017.

Joravsky, D. (1989). Russian Psychology: A Critical History (Oxford: Blackwell, 1989).

Kozulin, A. (1984). Psychology in Utopia: Toward a Social History of Soviet Psychology. Boston, MA: MIT.

Leontiev, A. (2005). The Life and Creative Path of A.N. Leontiev, Journal of Russian and East European Psychology, 43, 3, pp. 8-69.

Leontiev A.N., and A.V. Zaporozhets. (1960). Rehabilitation of Hand Function. Trans. by B. Haigh. London: Pergamon Press.

Levitin, K. E. (1998). The Soul's Frail Dwelling House. Journal of Russian and East European Psychology, 5(36), 23-45.

Luria, A. R. (2002). The Man with a Shattered World: The History of a Brain Wound. Trans. by L. Solotaroff. Cambridge, MA: Harvard University Press.

Luria, A. R. (1971). Poteriannyi $i$ vozrashchennyi mir: Istoriia odnogo raneniia [A World Lost and Regained: The Story of an Injury] Moscow: Izdatel'stvo MGU.

Luria, A. R. (1979). The Making of Mind: A Personal Account of Soviet Psychology. Edited by M. Cole and S. Cole. Cambridge, MA: Harvard University Press.

Luria, A. R. (1975). The Mind of a Mnemonist: A Little Book about a Vast Memory. London, Penguin Books.

Luria, A. R. (1974). A.R. Luria. A History of Psychology in Autobiography, vol. 6. ed. by G. Lindzey. Cambridge, MA: Harvard University Press, pp. 253-292.

Luria, A. R. (1932). The Nature of Human Conflicts or Emotion, Conflict and Will. Trans. by W. Horsley Gantt. New York, NY: Liveright.

Luria, A. R. (1970). Traumatic Aphasia: Its Syndromes, Psychology and Treatment. Trans. by Macdonald Critchley . The Hague: Mouton.

Luria, A. R. (1947). Travmaticheskaia Afasiia: Vosstanovitelnaia terapiia [Traumatic Aphasia: Rehabilitative Therapy. Moscow: Akademiia Medititsinskikh Nauk, SSSR. 
Luria, A. R. (1963). Restoration of Function after Brain Injury. Trans by O. Zangwill. London: Pergamom Press.

Luria, A. R. (1966) Higher Cortical Functions in Man. Trans. by B. Haigh. New York, NY: Basic Books.

Luria, A. R. (1973). The Working Brain: An Introduction to Neuropsychology. Trans. by Basil Haigh. New York, NY: Basic Books.

Luria, A. R. (1996) Romanticheskie Esse [Romantic Essays] Moscow: Pedagogika.

Malabou, C. (2012). The New Wounded. New York, NY: Fordham University Press.

Miller, M. A. (1998). Freud and the Bolsheviks: Psychoanalysis in Imperial Russia and the Soviet Union. New Haven, CA: Yale University Press.

Proctor, H. (2011). Neuronal Ideologies: Catherine Malabou in Light of A. R. Luria, Dandelion: Postgraduate Arts Journal and Research Network, 2, 1.

Proctor, H. (2020). Psychologies in Revolution: Alexander Luria's 'Romantic Science' and Soviet Social History. London:: Palgrave Macmillan.

Proctor H. and L., Salisbury (2015). The History of a Brain Wound: Alexander Luria and the Dialectics of Soviet Plasticity. Plasticity and Pathology: On the Formation of the Neural Subject. Ed. by David Bates and Nima Bassiri. Bronx, NY: Fordham University Press.

Rose, J. (1989). The "The Man Who Mistook His Wife for a Hat" or "A Wife Is like an Umbrella" - Fantasies of the Modern and Postmodern. Social Text, 1, 237-250.

Sacks, O. (2015a). Gratitude. London: Picador.

Sacks, O. (1973). The Mind of AR Luria'. The Listener. June 28, pp. 870-873.

Sacks, O. (1991). Awakenings. London: Picador.

Sacks, O. (2015b). On the Move: A Life. London: Picador.

Sacks, O. (1986). Clinical Tales. Literature and Medicine., 5, 16-23.

Sacks, O. (1985). The Man who Mistook his Wife for a Hat and Other Clinical Tales. New York, NY: Summit Books.

Sacks, O. (1984). A Leg to Stand On. London: Duckworth.

Sacks, O. (1977) Professor A. R. Luria. The Times, September 5, p. 14.

Stetsenko, A., \& I, Arievitch. (2004). Vygotskian Collaborative Project of Social Transformation: History, Politics, and Practice in Knowledge Construction. The International Journal of Critical Psychology., 12(4), 58-80.

van der Veer, R., \& Yasnitsky, A. (Eds.). (2016). Revisionist Revolution in Vygotsky Studies. London: Routledge.

Wortis, J. (1950). Soviet Psychiatry. Baltimore, ML: Williams and Wilkins Co.

Zajicek, B. (2009). Scientific Psychiatry in Stalin's Soviet Union: The Politics of Modern Medicine and the Struggle to Define 'Pavlovian' Psychiatry, 1939-1953'. PhD Thesis, University of Chicago.

Publisher's Note Springer Nature remains neutral with regard to jurisdictional claims in published maps and institutional affiliations. 